\title{
KARAKTERISTIK VISUAL ARSITEKTUR BANDARA DI JAWA TENGAH
}

\author{
Muhammad Fariz Hilmy ${ }^{1 *}$ Agung Budi Sardjono ${ }^{2}$, Edward E. Pandelaki ${ }^{3}$ \\ Departemen Arsitektur Fakultas Teknik, Universitas Diponegoro 1,2,3 \\ e-mail: *farizhilmym@gmail.com, ${ }^{2}$ agungbsardjono@gmail.com, ${ }^{3}$ epandelaki@gmail.com
}

\begin{abstract}
Abstrak_Bandara merupakan pintu gerbang masuk ke dalam sebuah provinsi atau daerah, sehingga sudah seharusnya bangunan bandara mengandung nilai-nilai kelokalan atau identitas daerahnya. Namun kini bandara di Jawa Tengah telah mengalami perubahan desain, dari yang lama yang masih kental dengan unsur kelokalan, menjadi yang baru yang penuh dengan unsur modern. Karakteristik visual dari kedua bandara ini tentunya berbeda. Meskipun bandaranya terletak di Jawa Tengah namun akan dilihat apakah masih terdapat karakter Jawa pada bangunannya atau muncul karakteristik visual yang lain. Metode deskriptif dan pendekatan rasionalistik kualitatif akan digunakan pada penelitian ini untuk mengidentifikasi kedua bandara untuk diketahui karakteristik visualnya melalui elemen-elemen yang ada pada kedua bandara tersebut. Hasil dari penelitian ini adalah persamaan elemen kedua bandara, namun menghasilkan karakteristik visual yang berbeda-beda, tergantung dari aspek visual (bentuk, permukaan, dimensi, dan identitas) dari elemen masing-masing bandara.
\end{abstract}

Kata kunci: Karakter Visual; Identitas; Arsitektur Bandara, Jawa Tengah.

\begin{abstract}
The airport is the gateway to enter into a province or region, so that airport buildings should contain locality or regional identity values. But now the airports in Central Java have undergone a design change, from the old ones that are still thick with the locality, to a new one full of modern elements. The visual character of the two types of airports is certainly different. Although the airport is located in Central Java, it will be seen whether there are still Javanese characters in the building or other visual characters. Descriptive methods and qualitative rationalistic approaches will be used in this study to identify the two airports to find out their visual characters through the elements at the two airports. The results of this study are differences in the visual character of the architecture of the two airports in Central Java at this time and the similarity of characters that show identity from the province of Central Java itself.
\end{abstract}

Keywords: Visual Character; Identity; Airport Architecture; Central Java.

\footnotetext{
${ }^{1}$ Departemen Arsitektur Fakultas Teknik, Universitas Diponegoro

${ }^{2}$ Departemen Arsitektur Fakultas Teknik, Universitas Diponegoro

${ }^{3}$ Departemen Arsitektur Fakultas Teknik, Universitas Diponegoro
} 


\section{PENDAHULUAN}

Pengaruh Globalisasi kini kian berdampak pada gaya hidup masyarakat Indonesia, tak terkecuali profesi arsitek. Arsitek-arsitek di Indonesia kini terus memenuhi idealismenya dalammendesain karya-karya arsitekturyang lebih mengarah pada arsitektur global.Hal ini membuat nilai-nilai kelokalan yang seharusnya dimiliki oleh sebuah bangunan menjadi dihiraukan karena lebih memilih untuk menggunakan nilai atau konsep arsitektur yang lain untuk diterapkan pada bangunannya. Konsep arsitektur yang bertolak-belakang dari nilai kelokalan ini membuat makna atau karakter yang ditimbulkan pun menjadi lain atau bahkan tidak bermakna sama sekali karena penampilan arsitektur dengan bentuk baru dapat bermakna tetap apabila hanya mengadopsi kebudayaan asingnya saja, tetapi menjadi berbeda apabila kebudayaan asing tersebut diterapkan secara utuh, maka makna yang dihasilkan menjadi makna yang baru (Kartono, 1999).

Sebagai contoh adalah bandara. Bandara disebut-sebut adalah pintu gerbang keluar dan masuknya pengunjung menuju sebuah daerah atau bahkan negara (Erawati \& Nuffida, 2017), dimana nilai kelokalan seharusnya muncul untuk menandakan adanya keberadaan atau identitas daerah pada bangunan bandara tersebut. Namun bandara di Indonesia, atau lingkup Jawa Tengah saja telah menunjukkan karakter yang terlepas dari unsur Jawa. Hal ini terlihat dari terminal Bandara Internasional Ahmad Yani di Semarang yang baru, dan juga Bandara Internasional Adi Soemarmo di Solo yang kini telah diperbaharui. Keduanya seperti hanya menekankan dimensi intelektual dan konseptual yang tidak menyentuh esensi sensual arsitektur, seperti penggunaan material kaca dan lapisan enamel yang sintetis, yang tidak menyampaikan apapun, tidak menyampaikan darimana ia berasal, lalu umur dan apa yang dialami material tersebut (Sabatini, Kurniati, Haristianti, \& Sudrajat, 2017).

Berdasarkan permasalahan tersebut, penelitian ini akan dilakukan untuk membahas mengenai perbedaan karakter visual kedua bandara di Jawa Tengah dan melihat persamaan karakter yang menunjukkan identitas dari budaya Jawa itu sendiri, karena meskipun kedua bandara tersebut sama-sama terletak di Jawa Tengah, namun karakter yang terwujud dari keduanya berbeda-beda. Karakter ini terwujud dari elemen dari bandara itu sendiri, serta persepsi dari pengamat arsitektur atau pengunjung bandara itu sendiri. Karakter dan elemen menjadi saling terkait. Oleh karena itu dalam membahas mengenai karakter visual, elemen tentu akan dilihat terlebih dahulu dan diidentifikasi lebih lanjut.

\section{METODE PENELITIAN}

Metode penelitian yang digunakan adalah metode deskriptif, dan dengan pendekatan rasionalistik kualitatif. Strategi penelitian yang digunakan adalah penelitian studi kasus jamak holistik karena obyek penelitian lebih dari satu unit yang sejenis (Arifianto, 2016). Selain penelitian studi kasus, penelitian visual juga digunakan pada penelitian ini yaitu dengan menggunakan fotografi atau gambar sebagai alat untuk melakukan wawancara dengan responden yang mengamati gambar tersebut (Sanoff, 1991).

Teknik pengambilan data sendiri dilakukan dengan observasi dan dokumentasi dengan melakukan tahapan mengidentifikasi aspek visual keseluruhan, karakter visual dari jarak dekat, serta karakter visual dari ruang interiornya (Nelson, 1988). Dari data tersebut akan dilakukan analisis dengan teknik analisis deskriptif yaitu mendeskripsikan keadaan atau hubungan antar fenomena yang diteliti secara sistematis, faktual, dan akural (Best \& Kahn, 2016). 


\section{HASIL DAN PEMBAHASAN}

\section{A. Karakter Visual dan Elemen Arsitektur}

Pembahasan mengenai karakter visual sebuah bangunan memiliki kaitan erat dengan elemen arsitektur yang membentuk bangunan tersebut. Karakter visual sebuah bangunan menurut Nelson (1988), diklasifikasikan menjadi beberapa tahapan, yaitu pada karakter yang terlihat pada keseluruhan bangunan dapat berupa bentuk bangunannya sendiri, atap, bukaan, proyeksi, perpotongan, material, hingga setting. Lalu pada karakter yang terlihat dari jarak dekat dapat berupa detail-detail material hingga ornamentasinya, serta karakter yang terlihat pada interior dapat berupa ruang individu, ruang serupa, permukaan finishing, hingga struktur yang tereskpos. Karakter yang ditangkap oleh pengamat dapat pula disebut representasi visual. Representasi visual diantaranya seperti tekstur, ukuran, linearitas, udara, lokasi, pegantian tekstur, kontinuitas, serta transisi.

Karakter-karakter visual tersebut hanya menunjukan karakter visual secara umum saja. Namun untuk beberapa daerah tertentu, terdapat bangunan-bangunan yang memiliki karakter khusus, yaitu karakter kelokalan atau identitas dari daerah setempat yang ditunjukan melalui bentuk khas daerah serta ornamen khas daerah itu sendiri. Teori-teori tersebut memiliki beberapa persamaan yang dapat dijadikan acuan penelitian yaitu karakter visual sebuah bangunan dapat dilihat dari

1) Bentuk bangunannya sendiri

2) Ukuran bangunannya terkait dengan proporsi massa bangunannya

3) Permukaan bangunan terkait warna serta tekstur pada material bangunan

4) Kelokalan atau identitas daerah terkait dengan bentuk khas serta ornamen

Karakater-karakter visual tersebut tentu tidak lepas dari perwujudan elemen arsitektur atau bangunannya. Secara umum, bangunan dibentuk oleh tiga elemen pembentuk ruang (Surasetja, 2007), diantaranya bidang alas/lantai, bidang dinding/pembatas, serta bidang langit-langit/atap. Lalu Berry (1980) menambahkan elemen pembatas atau dinding terdapat elemen vertikal atau Kolom, elemen horizontal atau balok, serta bukaan. Adapun Parolek (2008) melengkapi beberapa elemen arsitektur tersebut dengan adanya elemen massa bangunan, komposisi fasad, jendela dan pintu, elemen dan detail, serta warna dan kombinasi material. Namun yang menjadi dasar acuan penelitian ini cukup pada elemen dasar saja yaitu alas, dinding, atap, kolom, balok, serta bukaan, karena cukup mewakili semua elemen arsitektur.

\section{B. Karakter Visual dan Identitas}

Jawa Tengah memiliki dua bandara bertaraf internasional yang berada di Kota Semarang dan Solo. Kedua bandara ini secara tipologi memiliki dua bentuk bangunan yang berbeda. Tidak terlihat adanya elemen yang sekilas memiliki karakter atau identitas yang sama meskipun keduanya berdiri di wilayah atau provinsi Jawa Tengah. Jawa Tengah merupakan sebuah provinsi atau wilayah administratif dan tidak memiliki karakter atau budaya yang spesifik, karena yang memiliki karakter atau budaya adalah Jawa itu sendiri. Budaya Jawa sendiri memiliki ragam bentuk dan hias yang sangat bervariasi dan memiliki makna yang sangat dalam. Namun yang terlihat pada kedua bandara tersebut, budaya Jawa telah melebur dalam bentuk-bentuk yang modern dan bahkan telah sepenuhnya berbentuk modern. Sebagai pintu gerbang keluar dan masuknya pengunjung ke sebuah wilayah atau provinsi, kedua bandara ini memiliki karakter visual yang berbeda karena bentuk dan elemennya yang membuat pengunjung merasakan karakter visual yang lain atau tidak terasa karakter Jawa pada bangunannya. 


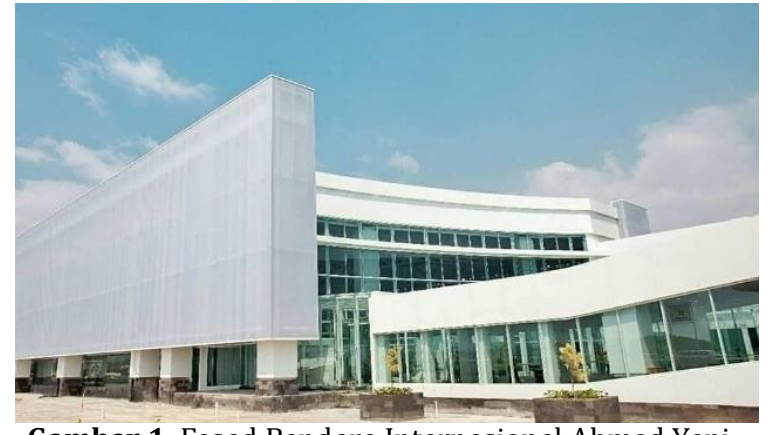

Gambar 1. Fasad Bandara Internasional Ahmad Yani Semarang

Sumber : Angkasa Pura, 2018

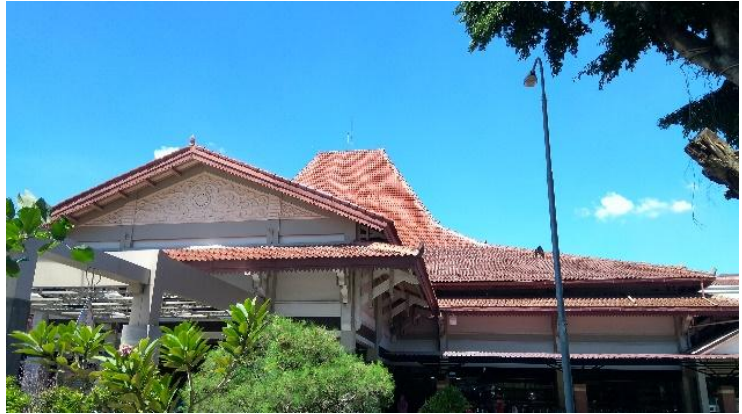

Gambar 2. Fasad Bandara Internasional Adi Soemarmo, Solo

Sumber : Dokumentasi Lapangan, 2019

Terlihat bahwa dari fasad dapat dinilai bahwa kedua bandara tersebut memiliki kedua karakter visual yang berbeda. Meskipun sejarah mengatakan bahwa Bandara Internasional Ahmad Yani (lihat gambar 1) adalah bandara baru sedangkan Bandara Internasional Adi Soemarmo (lihat gambar 2) adalah bandara lama, bukan berarti elemen-elemen kelokalan atau budaya Jawa tidak diterapkan pada kedua bangunan tersebut. Namun bila ditelaah lebih dalam, dapat ditemukan beberapa elemen yang memberikan atau mewujudkan karakter kelokalan atau identitas masing-masing kota. Hal ini yang mungkin diterapkan oleh kedua bandara tersebut, karena identitas termasuk dalam salah satu dari tiga komponen untuk menganalisis citra sebuah kawasan atau obyek, yang merupakan citra mental yang terbentuk dari ritme tempat dan ruang yang mencerminkan sense of time yang ditumbuhkan dari dalam yang berasal dari aktivitas sosial, ekonomi, budaya yang mengakar pada masyakarat(Lynch, 1975), sehingga identitas ini apabila diimplementasikan dalam bangunan akan membuat bangunan tersebut memiliki karakter identitas kota yang kuat, karean dapat membentuk atau menumbuhkan citra mental bagi pengamat yang melihatnya, dan tentunya identitas kota lebih menekankan pada aspek visual dari fisik suatu kota (Permana \& Wijaya, 2013).

\section{Bandara Internasional Ahmad Yani}

Karakter visual pada Bandara Internasional Ahmad Yani terlihat pada elemen-elemen yang membentuknya. Beberapa kriteria elemen yang dilihat tentunya tidak jauh dari bentuk bangunannya serta implementasi identitas kota atau budaya Jawa yang ada pada bangunan tersebut. karena bangunan ini merupakan bangunan baru yang baru diresmikan tahun 2018 maka bentuk dan desainnya pun sesuai dengan eranya. Berikut adalah elemen-elemen pada bangunan terminal Bandara Internasional Ahmad Yani dilihat dari karakter-karakter berikut ini.

1. Bentuk/Wujud Bangunan

Secara keseluruhan, bentuk bangunannya sendiri didominasi dengan bentuk-bentuk rigid atau kaku, tidak banyak unsur lengkungan atau eksplorasi desain yang dekonstruktif, namun lebih pada desain-desain minimalis dan modern. Bentuk-bentuk tersebut terwujud pada hampir seluruh elemen bangunan mulai dari dinding, atap, hingga lantainya, namun yang terlihat dominan ada pada fasad bangunannya.Terlihat pada fasad depan terminal (lihat gambar 3)yang polos dan sederhana, dengan variasi atau permainan bentuk persegi yang disusun acak dan membentuk seperti labirin atau matriks, yang berfungsi sebagai double skin. 


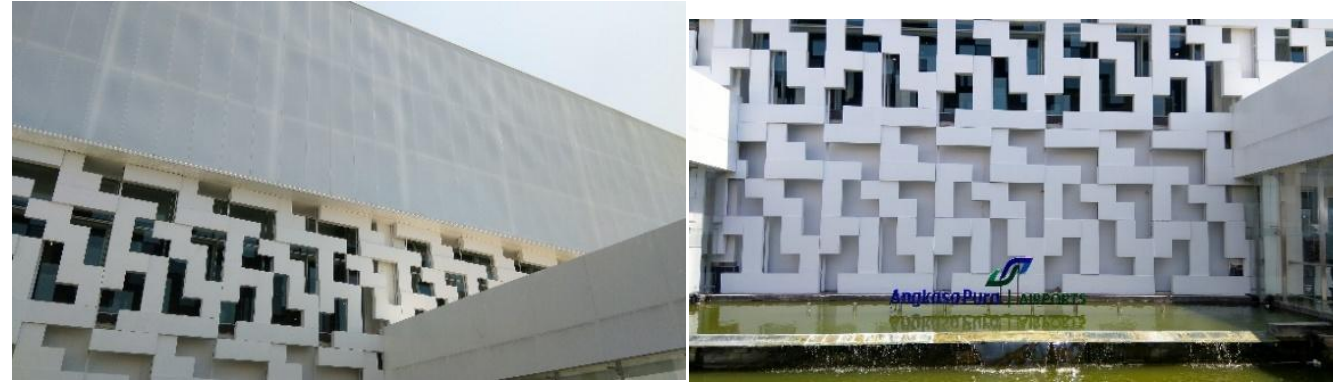

Gambar 3. Bentuk bangunan terminal Bandara Internasional Ahmad Yani Sumber : Dokumentasi Lapangan, 2019

\section{Dimensi/Proporsi Bangunan}

Terminal ini memiliki skala bangunan yang besar atau setara dengan bangunan dua hingga tiga lantai. Terlihat dari jarak antar lantai dengan plafon sekitar 4 hingga 5 meter yang membuat bangunan terminal tersebut menjadi tinggi dan besar. Proporsi antar massa bangunan terlihat bahwa ada massa bangunan yang menonjol sebagai bagian dari permainan fasadnya. Hal tersebut ada pada area keberangkatan (lihat gambar 4) dan area kedatangan. Elemen yang mewujudkan karakter tersebut terlihat pada fasad, serta ruangan-ruangan pada terminal seperti area check-in, area tunggu boarding, serta area tunggu pada lobby.
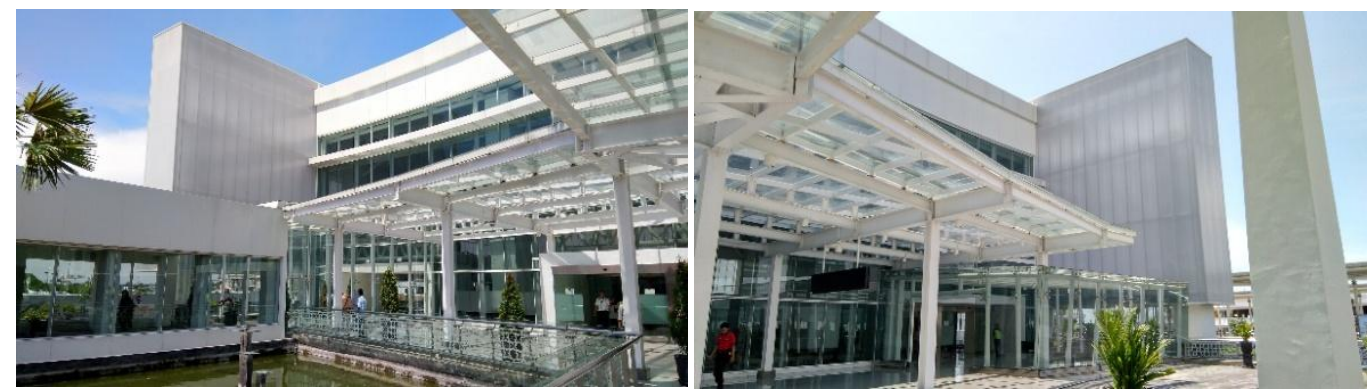

Gambar 4. Proporsi bangunan terminal Bandara Internasional Ahmad Yani Sumber : Dokumentasi Lapangan, 2019

\section{Warna/Tekstur Bangunan}

Pemilihan warnanya sendiri hampir keseluruhan bangunan dari eksterior hingga interior didominasi warna putih dan abu-abu. Warna-warna tersebut juga dijajarkan dengan material-material seperti baja dan kaca yang menambah kesan modern pada bangunan tersebut (lihat gambar 5). Karena pada dasarnya bandara tersebut mengangkat konsep eco-airport (Pura, 2018), maka pemilihan materialnya pun lebih pada elemenelemen yang ramah lingkungan dan tidak menimbulkan banyak energi buatan didalamnya.

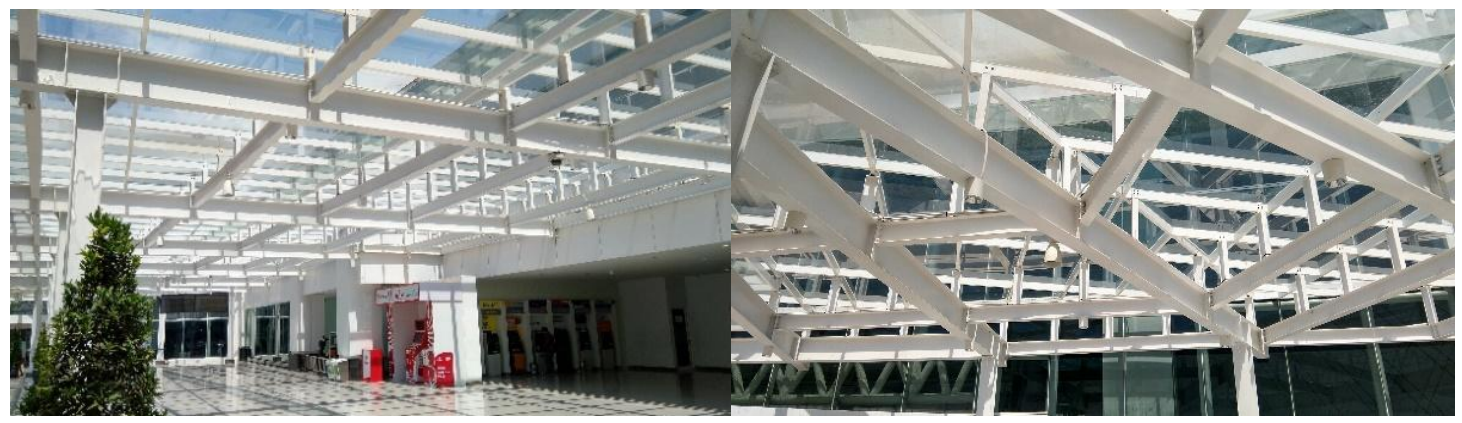

Gambar 5. Material bangunan terminal Bandara Internsional Ahmad Yani Sumber : Dokumentasi Lapangan, 2019 


\section{Kelokalan/Identitas}

Sejauh ini, bentuk-bentuk tersebut tidak mencirikan identitas budaya Jawa ataupun Kota Semarang. Namun terdapat elemen yang memiliki konsep berbeda dari konsep modern yang diterapkan bandara tersebut secara keseluruhan, yaitu terdapat implementasi budaya Jawa yang diterapkan pada taman-taman terapung di area kedatangan dan keberangkatan, yaitu miniatur atau replika Klenteng Sam Po Kong (lihat gambar 6) dan Gereja Blenduk (lihat gambar 7). Pura (2018) menyebutkan bahwa elemenelemen tersebut adalah bagian dari implementasi budaya Jawa, namun bila dilihat dengan ilmu arsitektur, kedua replika landmark kota tersebut tidaklah mencerminkan budaya Jawa, karena makna yang dihasilkan pun tidak menimbulkan makna Jawa. Seperti yang dijelaskan oleh Kartono (1999) bahwa penampilan arsitektur meksipun dengan bentuk yang lama yang ditempatkan pada bentuk baru, itu hanyalah sebagai tempelan (ornamentatif atau dekoratif), sehingga tidak dapat disebut bermakna tetap. Oleh karena itu, elemen landmarktersebut tidak dapat disebut memiliki karakter atau budaya Jawa, karena hanya merupakan ornamen dekoratif saja yang memberikan informasi atau karakter visual mengenai identitas Kota Semarang, tetapi bukan identitas Jawa. Selain kedua elemen tersebut, adapun elemen dekoratif lain yaitu mural pada dinding di area kedatangan yang menggambarkan ikon-ikon kota Semarang (lihat gambar 8). Elemen ini tentu juga tidak memberikan karakter visual Jawa melainkan karakter visual Kota Semarang itu sendiri. Selain beberapa elemen yang telah disebutkan diatas, tidak ditemukan adanya elemen budaya Jawa seperti ornamen khas Jawa atau bentuk-bentuk khas Jawa, sehingga bandara tersebut tidak dapat disebut memiliki kerakter visual Jawa melainkan lebih pada identitas Kota serta karakter yang modern.

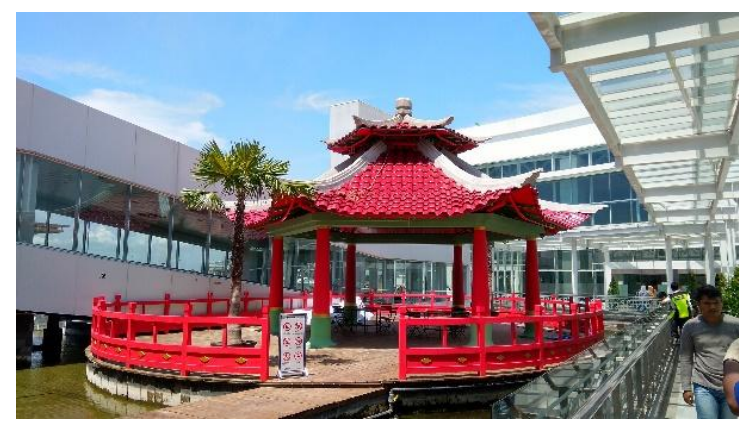

Gambar 6. Replika Klenteng Sam Po Kong Sumber : Dokumentasi Lapangan, 2019

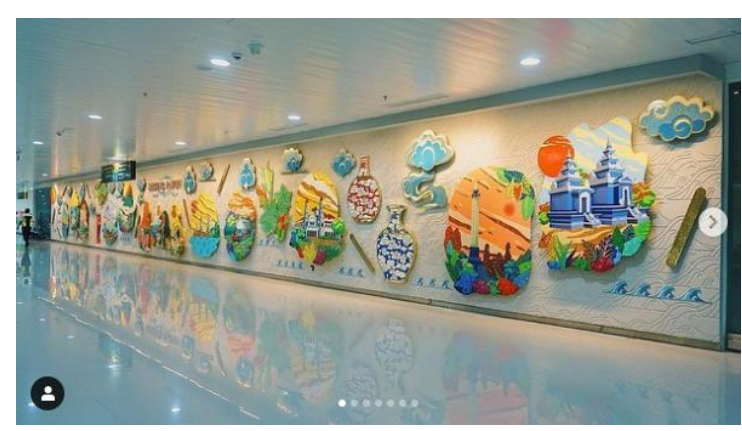

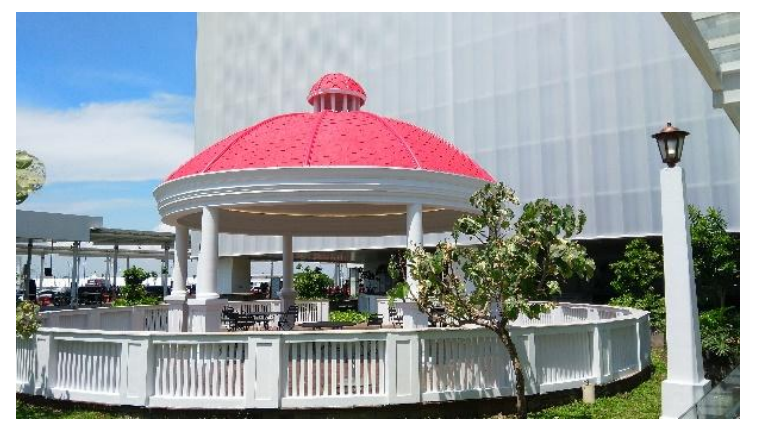

Gambar 7. Replika GerejaBlenduk Sumber : Dokumentasi Lapangan, 2019

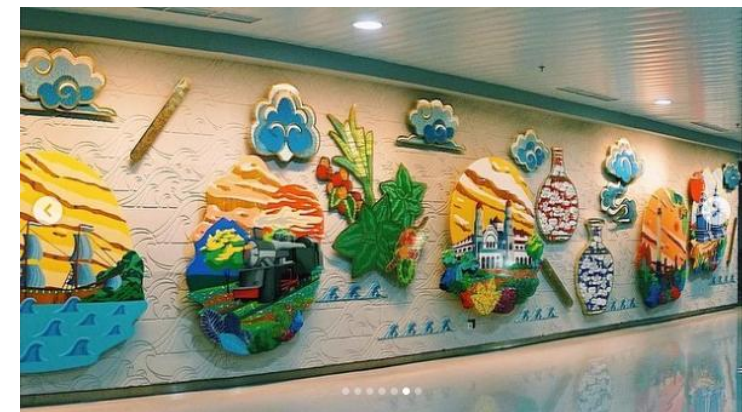

Gambar 8. Mural ikon-ikon Kota Semarang Sumber : Dokumentasi Lapangan, 2019 


\section{Bandara Internasional Adi Soemarmo}

Karakter visual bandara Internasional Adi Soemarmo secara sekilas cukup berbeda dari Bandara Internasional Ahmad Yani. Telah disebutkan sebelumnya bahwa Bandara Internasional Adi Soemarmo adalah bandara lama yang tidak membangun bandara baru dengan bentuk yang baru seperi Bandara Internasional Ahmad Yani, sehingga bentuk dan desain bangunannya merupakan desain yang sesuai pada era saat bandara tersebut terbangun yaitu sekitar tahun 1940 hingga 1977. Berikut adalah elemen-elemen pada bangunan terminal Bandara Internasional Adi Soemarmo dilihat dari karakter-karakter berikut ini.

1. Bentuk/Wujud Bangunan

Secara keseluruhan, bangunan terminal ini terlihat memiliki bentuk rumah adat Jawa dengan aplikasi bentuk atap Joglo (lihat gambar 9). Selain bentuk atap Joglo, bentuk elemen dasar bangunannya seperti dinding dan lantai juga tidak banyak eksplorasi bentuk dan terlihat seperti gedung pada umumnya. Bentuk yang terlihat signifikan memang pada atap bangunan saja, karena pada elemen lain tidak ditemukan bentuk-bentuk lain yang signifikan. Dinding serta lantai maupun kolom dan balok terlihat standart dan berbentuk rigid seperti bangunan rumah tinggal pada umumnya, hanya saja ini diaplikasikan pada bangunan skala besar.

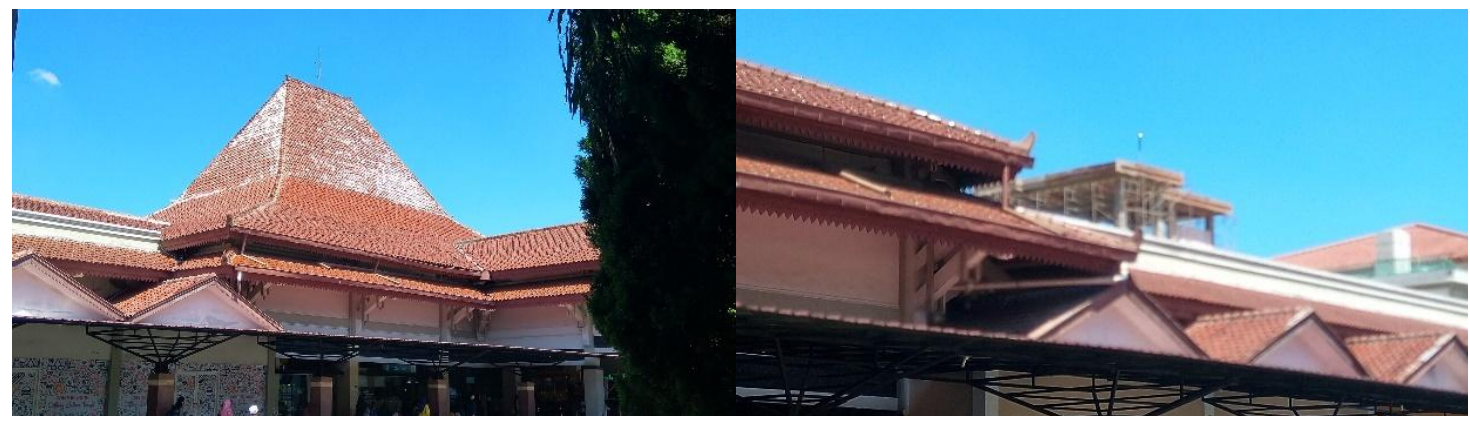

Gambar 9. Bentuk Atap Joglo pada terminal Bandara Internasional Adi Soemarmo Sumber : Dokumentasi Lapangan, 2019

2. Dimensi/Proporsi Bangunan

Dimensi dan proporsi bangunan terminal ini terlihat menonjol pada bagian atap, karena terlihat memiliki ukuran atap yang besar dan tinggi.Hal ini membuat bangunan terminal terlihat proporsional karena diimbangi dengan pengaplikasian atap lain disekitar atap Joglo tersebut (lihat gambar 10), seperti atap pelana pada area drop off dan juga beberapa atap pelana pada fasad. Dari segi interior, bangunan terdiri dari satu lantai utama dengan ketinggian plafon 4 hingga 5 meter, terlihat pada area lobby serta area tunggu boarding.

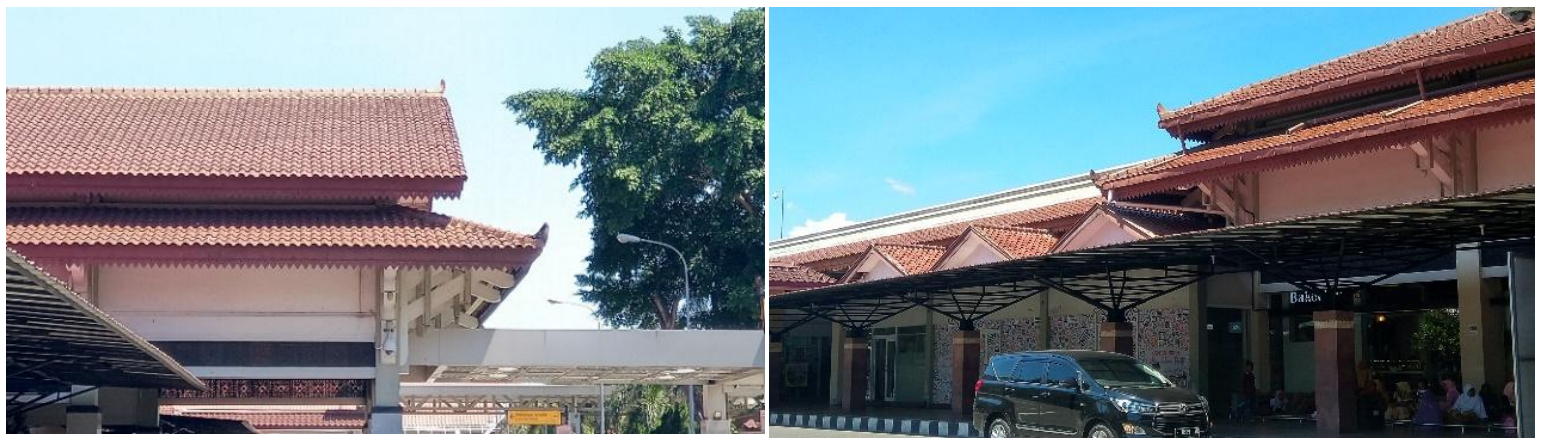

Gambar 10. Variasi atap dan material Bandara Internasional Adi Soemarmo Sumber : Dokumentasi Lapangan, 2019 
3. Warna/Tekstur Bangunan

Secara keseluruhan tema warna dari terminal ini adalah warna-warna netral dan tidak jauh dari warna budaya Jawa yang berwarna cokelat keemasan, yang terlihat pada detail ornamen pada dinding dan juga plafon (lihat gambar 11). Balok dan kolom juga berwarna putih kecokelatan dan ornamennya berwarna cokelat tua. Pemilihan material pada bangunan ini seperti bangunan pada umumnyadan tidak terlalu menggunakan material dengan teknologi yang canggih yaitu menggunakan bata dan beton, dan genting pada atapnya karena masih menggunakan konsep atap tradisional.

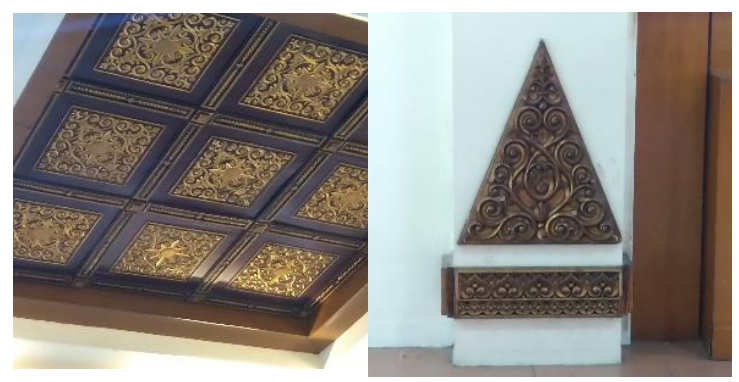

Gambar 11. Warna ornamen pada plafon dan kolom Bandara Internasional Adi Soemarmo Sumber : Dokumentasi Lapangan, 2019

\section{Kelokalan/Identitas}

Secara keseluruhan bandara ini memiliki bentuk-bentuk khas Jawa. Bila dilihat lebih dekat, terdapat pula elemen-elemen dekoratif yang mencirikan budaya Jawa seperti ornamen-ornamen yang dapat ditemukan pada sopi-sopi atap (lihat gambar 3.12), lalu adanya replika gunungan di koridor menuju pintu masuk bandara (lihat gambar 3.13), serta ornamen pada kanopi menuju pintu masuk bandara (lihat gambar 3.14). Beberapa elemen dekoratif dan ornamentasi tersebut meskipun dikemas dengan material yang bukan merupakan material asli khas Jawa seperti kayu, melainkan material modern seperti besi dan beton, namun makna dari ornamen tersebut masih memiliki makna Jawa yang cukup kental. Seperti halnya yang dikatakan oleh Kartono (1999) bahwa penampilan arsitekturnya menghadirkan bentuk baru dalam artian unsur-unsur lama yang diperbaharui, maka makna arsitekturnya masih tetap dengan makna yang lama.

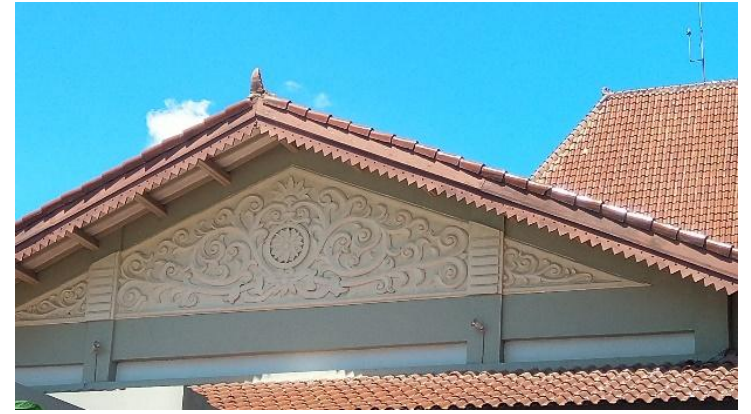

Gambar 12. Detail Ornamen Sopi-Sopi Sumber : Dokumentasi Lapangan, 2019

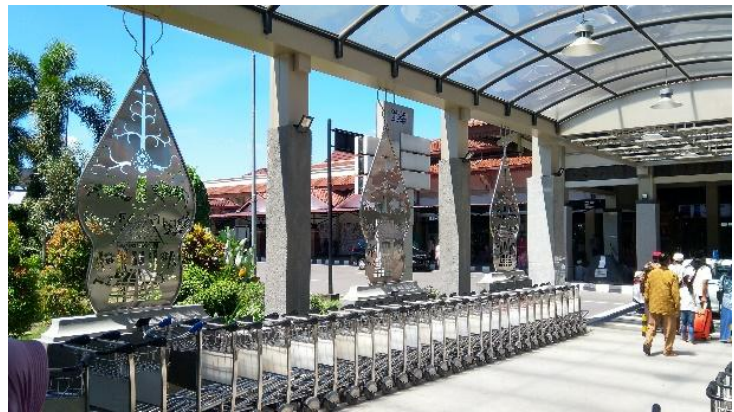

Gambar 13. Replika Gunungan di Koridor Sumber : Dokumentasi Lapangan, 2019 

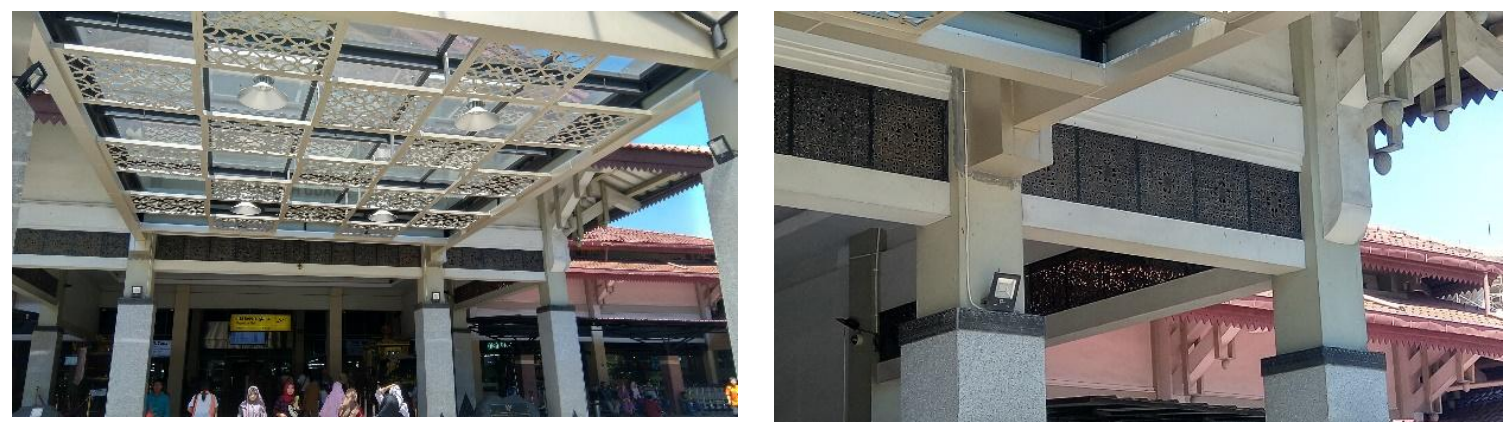

Gambar 14. Detail Ornamen Kanopi Sumber : Dokumentasi Lapangan, 2019

\section{KESIMPULAN}

Berdasarkan hasil temuan elemen visual yang ada pada kedua bandara di Jawa Tengah, yaitu Bandara Internasional Ahmad Yani dan Bandara Internasional Adi Soemarmo, dapat disimpulkan bahwa keduanya memiliki karakter visual yang berbeda. Meskipun keduanya berada pada satu wilayah administratif yaitu provinsi Jawa Tengah, namun tidak ada pakem-pakem yang disepakati atau elemen-elemen yang serupa pada kedua bandara. Keduanya memiliki karakternya sendirisendiri dan terwujud dari elemen-elemen yang diterapkannya saat ini. Meskipun keduanya memiliki karakter visual yang berbeda, kedua bandara ini masih menerapkan konsep lokal serta budaya pada bandaranya meskipun dikemas dengan material yang modern, seperti bandara Internasional Ahmad Yani yang memberikan replika landmark Kota Semarang serta mural ikonikon Kota Semrang dan Bandara internasional Adi Soemarmo yang memberikan ornamen-ornamen khas Jawa pada setiap elemen dasar bangunan (atap, dinding, lantai).

Oleh karena itu, dapat disimpulkan bahwa hanya Bandara Internasional Adi Soemarmo yang dapat mewujudkan karakter visual Jawa pada setiap elemen yang diterapkan pada bandara tersebut, sedangkan Bandara internasional Ahmad Yani tidak mewujudkan karakter tersebut, melainkan lebih pada karakter identitas Kota Semarang nya sendiri. Bandara Internasional Adi Soemarmo tidak menerapkan identitas Kota Solo namun dari ornamen-ornamen tersebut sudah menunjukan bahwa Kota Solo memiliki identitas budaya yang kuat, karena bila dilihat dari segi kawasan Kota Solo sendiri, hampir disetiap sudut kota menerapkan ornamen-ornamen di setiap elemen kotanya, termasuk bangunan-bangunannya, sehingga tidak perlu ada replika landmark Kota Solo untuk mewujudkan karakter identitas Kota Solo pada Bandara Internsional Adi Soemarmo itu sendiri. 


\section{DAFTAR REFERENSI}

Arifianto, S. (2016). Implementasi Metode Penelitian Studi Kasus dengan Pendekatan Kualitatif. Yogyakarta: Aswaja Pressindo.

Berry, W. (1980). Good Neighbours, Building Next to History. Colorado: Historical Society of Colorado.

Best, J. W., \& Kahn, J. V. (2016). Research in Education. Chennai: Pearson India.

Erawati, D., \& Nuffida, N. E. (2017). Pelestarian Identitas Arsitektural Lokal melalui Redesain Terminal Bandar Udara. Jurnal Sains dan Seni ITS, Vol.06, No.01, 20-22. Diambil kembali dari http://ejurnal.its.ac.id/index.php/sains_seni/article/view/22609

Kartono, J. L. (1999). Konsep Arsitektur Rumah Tinggal Tradisional Nusantara dan Pola Perubahannya. Dalam S. Aly, Ngawangun Ki Nusantara. Bandung: Arsitektur Unpar.

Lynch, K. (1975). The Image of The City. Dalam E. Budihardjo, Jati Diri Arsitektur Indonesia (hal. 114). Cambridge: The MIT Press.

Nelson, L. H. (1988). Architectural Character : Identifiying the Visual Aspects of Historic Buildings as an Aid to Preserving Their Character. Washington DC: U.S. Department of the Interior National Park Service Cultural Resources.

Parolek, D. G. (2008). Form Based Codes : A Guide for Planners, Urban Designers, Municipalities, and Developers. London: John Wiley \& Sons.

Permana, A. Y., \& Wijaya, K. (2013). Kota Bandung : Kota Pendidikan antara Citra dan Identitas Kota. Semnas Reinterpretasi Identitas Arsitektur Nusantara, (hal. 27-34). Bali.

Pura, A. (2018). Terminal Baru Bandara Internasional Ahmad Yani. Semarang: Angkasa Pura Airport.

Sabatini, S. N., Kurniati, F., Haristianti, V., \& Sudrajat, I. (2017). Sumbangsih Juhani Pallasmaa dalam Teori Arsitektur. Jurnal RUAS, Vol.15,No.02, 49-60. Diambil kembali dari https://ruas.ub.ac.id/index.php/ruas/article/view/242

Sanoff, H. (1991). Visual Research Methods in Design. New York: Van Nostrand Reinhold.

Surasetja, I. (2007). Fungsi, Ruang, Bentuk dan Ekspresi dalam Arsitektur. Bahan Ajar Pengantar Arsitektur, 1-13. 